удК 637.54

05.00.00 Технические науки

\section{ОЦЕНКА ПОТРЕБИТЕЛЬСКИХ СВОЙСТВ ДЕЛИКАТЕСОВ ИЗ МЯСА КРОЛИКА}

\author{
Волкова Ольга Васильевна \\ к.т.н., доцент \\ РИНЦ SPIN-код: 3769-7446 \\ volkova-olga72@mail.ru \\ Есенбаева Камиша Саитовна \\ к.с-х.н., доцент \\ РИНЦ SPIN-код: 8489-8379 \\ eks-tsaa@yandex.ru \\ ФГБОУ ВО «Государственный аграрный \\ университет Северного Зауралья», \\ Россия, 625003, г. Тюмень, \\ ул. Республики,д.7
}

Одним из перспективных вариантов развития мясной отрасли может стать производство продуктов из нетрадиционных видов мясного сырья, таких как мясо кролика, которое обладает высоким содержанием белка, обеспеченного полным набором незаменимых аминокислот, широким спектром минеральных веществ и витаминов при пониженном содержании жира. В связи с этим в последние годы значительно повысился спрос на деликатесы из мяса кроликов. Мясо кроликов широко используют в виде различных кулинарных блюд в диетическом питании. В ограниченных масштабах мясо кроликов используют при производстве колбасных изделий. Производство деликатесных полноценных продуктов из крольчатины, способных к длительному хранению, практически не разработано. В соответствии с разработанной рецептурой и технологией производства рулетов копченовареных из мяса кролика установлены регламентируемые требования, предъявляемые к качеству рулетов и внесенные в ТУ. По результатам органолептической оценки все образцы продуктов получили хорошие баллы. По показателям химического состава продукты удовлетворяют требованиям: массовая доля белка - не менее $20 \%$, массовая доля жира - не более $25 \%$, массовая доля влаги - не более $65 \%$. Разработанные деликатесные продукты обладают высокой пищевой и биологической ценностью

Ключевые слова: МЯСО КРОЛИКА, РУЛЕТЫ КОПЧЕНО-ВАРЕНЫЕ, ХИМИЧЕСКИЙ СОСТАВ, ОРГАНОЛЕПТИЧЕСКАЯ ОЦЕНКА, КАЧЕСТВО, БИОЛОГИЧЕСКАЯ ЦЕННОСТЬ
UDC 637.54

Technical Sciences

\section{ESTIMATION OF CONSUMER PROPERTIES OF DELICACY FROM RABBIT MEAT}

Volkova Olga Vasilievna

Cand.Tech.Sci, Associate Professor

RSCI SPIN-code: 3769-7446

volkova-olga72@mail.ru

Esenbaeva Kamisha Saitovna

Cand. of Agricultural Sci., Associate Professor

RSCI SPIN-code: 8489-8379

eks-tsaa@yandex.ru

Federal State-Funded Educational Institution of

Higher Education "Northern Trans-Ural State

Agricultural University”, 625003, Russia, Tyumen

Region, Tyumen, ul.Respubliki, 7

One of perspective variants of development of the meat industry can become the production of foodstuffs from untraditional kinds of the meat raw materials such as the rabbit meat, which has a high protein content with a full number of essential amino acids, broad spectra of the mineral substances and vitamins and reduced fat content. Therefore, a demand on the rabbit meat has been increased significantly in the past years. Rabbit meat is widely used in various culinary dishes of the dietary nutrition. Rabbit meat is used in limited scales for production of sausages. The production of the delicacy sterling foodstuffs from the rabbit meat, that are capable for long-term storage, is almost not developed. The regulated requirements for quality of rolls that are included in Technical Conditions are set up in accordance with the developed recipe and technology of production of the smoked-boiled rolls from the rabbit meat. All the foodstuff samples gained high scores on the organoleptic estimation. The foodstuffs satisfy the requirements for chemical composition: mass fraction of protein - no less than $20 \%$, mass fraction of fat - no more than $25 \%$, mass fraction of moisture - no more than $65 \%$. The developed delicacy foodstuffs have a high nutritional and biological value

Keywords: RABBIT MEAT, SMOKED-BOILED

ROLLS, CHEMICAL COMPOSITION, ORGANOLEPTIC ESTIMATION, QUALITY, BIOLOGICAL VALUE

\title{
Doi: 10.21515/1990-4665-132-018
}


Стратегической целью, сформулированной в доктрине о продовольственной безопасности, является обеспечение населения страны безопасной сельскохозяйственной продукцией и продовольствием. Гарантией ее достижения является стабильность внутреннего производства в объемах и ассортименте, которые соответствуют рациональным нормам потребления пищевых продуктов, необходимых для активного и здорового образа жизни [1].

В структуре потребительского спроса в России рынок колбасных и деликатесных изделий является одним из крупнейших и динамичных рынков продовольственных товаров. Он имеет весьма устойчивые традиции, и его состояние оказывает существенное влияние на другие рынки продуктов питания. Для него характерен более высокий уровень конкуренции.

На сегодняшний день значительную часть традиционно занимают мясные деликатесы, в том числе копчено-вареные. Эти изделия входят в обязательный ассортимент большинства мясоперерабатывающих предприятий России.

Производство высококачественных мясных деликатесов достаточно трудоемкий и сложный процесс, для осуществления которого необходимо точное соблюдение всех технологических режимов, начиная от выбора сырья и заканчивая термической обработкой.

При разработке нового мясного деликатеса исследовали возможность использования мяса кроликов. Крольчатина всегда считалась деликатесным и диетическим продуктом она относится к так называемому белому мясу, ее мышечная ткань состоит из белка, в котором количество и соотношение незаменимых аминокислот близко к идеальному, она обладает высокими вкусовыми достоинствами, легко переваривается и усваивается организмом человека на 93\% [2].

В настоящее время в РФ деликатесные мясные продукты из мяса 
кролика вырабатываются в ограниченном количестве, в связи с этим, целью исследования являлась разработка рулетов копчено-вареных.

Данные пищевой ценности и технологических свойств мяса кроликов в ранее проведенных исследованиях [3-4], положены в основу создания рецептуры рулетов копчено-вареных.

В целях оптимизации и рационализации переработки мяса кроликов нами были разработаны образцы копчено-вареных продуктов из мяса кроликов: рулет «Тюменский» и рулет «Застольный», которые отличались технологией их изготовления. Эти продукты были разработаны в лаборатории технологии мяса и мясопродуктов ГНУ СибНИПТИП Россельхозакадемии.

При составлении рецептуры руководствовались рекомендациями Продовольственного комитета Всемирной организации здравоохранения и традиционными технологиями производства копчено-вареных изделий из мяса других видов животных, для получения биологически полноценного продукта необходимо соблюдать отношение белок и жир $(1: 1,2)$, поэтому в состав рецептуры рулетов введен свиной шпик, который придает мясным продуктам нежность и сочность. Разработанные образцы рулетов из мяса кроликов отличались технологией их изготовления [3].

Рецептура рулетов из крольчатины включает: мясо кролика обваленное - 90 кг, шпик свиной хребтовый - 10кг.

Процесс получения рулетов из крольчатины состоит из следующих операций. После обвалки мяса кроликов из половины мышечной ткани нарезали пластинки, другую часть измельчили на волчке в шрот с диаметром отверстий решетки 20-25 мм. Свиной хребтовый шпик, нарезали на кусочки размером 5х10 мм, солили и охлаждали. Затем мясо загружали в массажер и добавляли посолочную смесь (соль, сахар, нитрит натрия). Массирование осуществляли до образования на кусках липкой поверхности. Далее мясное сырье выдерживали при температуре $2-4^{0} \mathrm{C}$ в 
течение 26 ч. После посола сырье перемешивали 5-10 мин в мешалке со специями в соответствии с рецептурой с добавлением охлажденного шпика. После выдержки образцы формовали, упаковывали в целлофан, заключали в оболочку и направляли на термообработку. Варили в термокамере при температуре $75-85^{\circ} \mathrm{C}$ до температуры в центре батона $72^{0} \mathrm{C}$, затем подпрессовывали 7 часов при температуре не выше $12^{0} \mathrm{C}$, затем охлаждали до $10^{0} \mathrm{C}$. Готовые мясные продукты обработали $10 \%$ раствором сорбата калия, путем опрыскивания.

Комплексную оценку органолептических показателей, изучаемых образцов рулетов проводили по 9-ти бальной шкале [5] (рис.1).

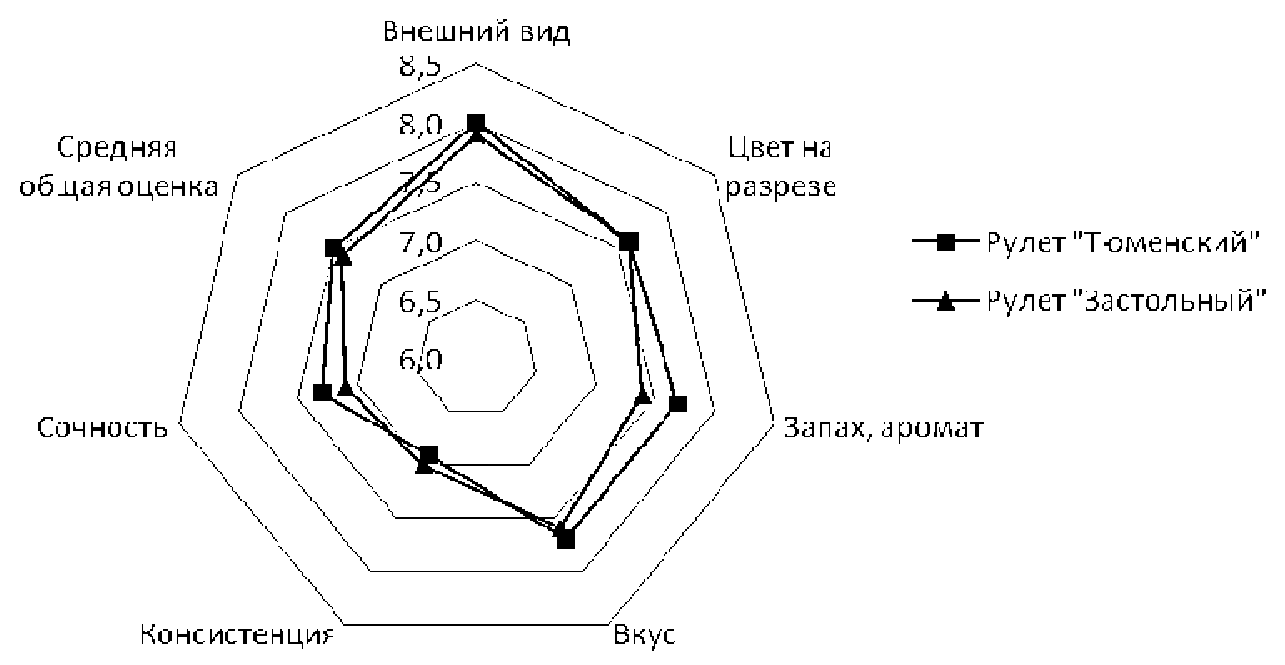

Рис. 1 Профилограмма органолептических показателей рулетов

Полученные результаты свидетельствуют, что рулет «Тюменский» имеет более высокие оценки по ряду показателей, в частности, дегустаторами отмечен более привлекательный внешний вид, это обусловлено выраженным цветом поверхности, ее глянцевостью и отсутствием отёков. Также рулет имеет усиленный мясной запах. Более высокая балльная оценка сочности обусловлена тем, что начинка рулета имеет фаршевую основу.

Рулет «Застольный» за внешний вид получил 7,9 баллов, за аромат 
- 7,4 балла, а за цвет и вкус по 7,6 балла.

Консистенция обоих рулетов была несколько жестковатой, что объясняется специфичностью сырья.

Как видно из представленных диаграмм у исследуемых продуктах хорошие органолептические показатели.

Известно, что химический состав мясных продуктов в значительной степени определяет их пищевую ценность и потребительские свойства.

Химический состав рулетов представлен на рисунке 2.

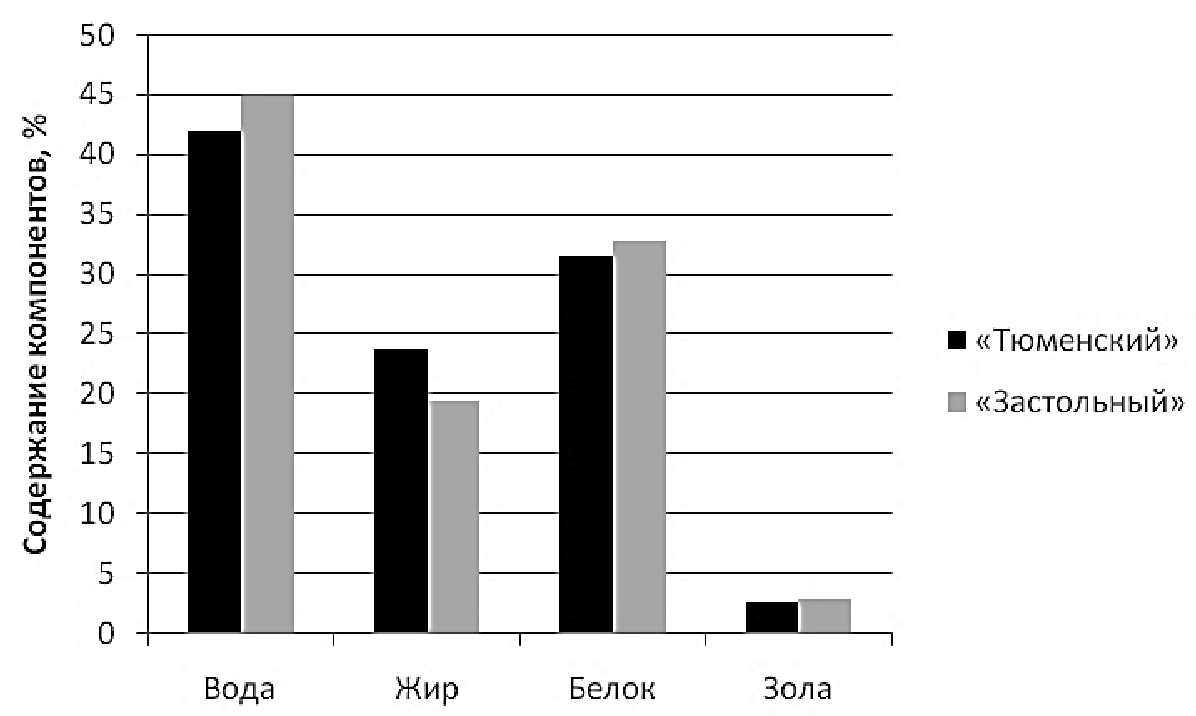

Рис. 2 Химический состав рулетов копчено-вареных, \%

Результаты исследований свидетельствуют о том, что наибольшее содержание белка и влаги содержится в рулете «Застольный». Это обусловлено структурой сырья, т.е. большим содержанием мышечного белка. В тоже время в рулете «Тюменский» содержится на 4,3\% больше жира, что обусловлено меньшими потерями при термической обработке. Соотношение белок: жир для рулетов «Тюменский» и «Застольный» составило соответственно 1,33 и 1,68. По количеству зольных веществ исследуемые рулеты имели незначительные различия.

Исходя из химического состава, рассчитана энергетическая ценность готовых продуктов, которая составила для рулета «Тюменский» - 
306,54 ккал, а для рулета «Застольный» - 340,24 ккал.

Средняя суточная потребность взрослого человека в белках составляет 80-100 г, в том числе животного - 50 г, то есть 100 г рулета удовлетворяют суточную потребность человека в животных белках на 63$65 \%$.

В таблице 1 представлен аминокислотный состав рулетов копченовареных.

Таблица 1 - Аминокислотный скор рулетов копчено-вареных

\begin{tabular}{|l|l|l|l|l|l|}
\hline \multirow{2}{*}{ Аминокислота } & \multicolumn{5}{|l|}{ Содержание аминокислоты (г/100 г белка / скор, \%) } \\
\cline { 2 - 6 } & $\begin{array}{l}\text { Эталон } \\
\text { ФАО/ВО3 }\end{array}$ & \multicolumn{1}{|l|}{ Рулет «Тюменский» } & \multicolumn{1}{|l|}{ Рулет «Застольный» } \\
\cline { 3 - 6 } & г/100 г & Скор,\% & г/100 г & Скор,\% \\
\hline Изолейцин & 4,0 & 4,75 & 118,7 & 4,94 & 123,5 \\
\hline Лейцин & 7,0 & 7,66 & 109,4 & 7,61 & 108,7 \\
\hline Лизин & 5,5 & 6,71 & 122,0 & 6,57 & 119,4 \\
\hline $\begin{array}{l}\text { Метионин+ } \\
\text { Цистин }\end{array}$ & 3,5 & 3,65 & 104,3 & 3,64 & 104,0 \\
\hline $\begin{array}{l}\text { Фнилаланин+ } \\
\text { Тирозин }\end{array}$ & 6,0 & 7,20 & 120,0 & 7,50 & 125,0 \\
\hline Треонин & 4,0 & 4,54 & 113,5 & 4,57 & 114,2 \\
\hline Триптофан & 1,0 & 1,72 & 172,0 & 1,77 & 177,0 \\
\hline Валин & 5,0 & 5,43 & 108,6 & 5,40 & 125,0 \\
\hline Сумма НАК & 36,0 & 41,76 & & 42,0 & \\
\hline
\end{tabular}

Анализируя данные таблицы установили, что как по сумме, так и по содержанию большинства отдельных незаменимых аминокислот белок мяса кроликов превышает эталонный белок. Известно, что увеличение содержания аминокислот является свидетельством повышения биологической ценности продуктов.

Наиболее важными аминокислотами в процессе созревания являются ароматические соединения (фенилаланин и тирозин) и серосодержащие (метионин и цистин). Суммарное содержание фенилаланина и тирозина в исследуемых образцах составило соответственно 7,2, и 7,5. 
Следовательно, использование коптильного ароматизатора и специй в образцах рулетов способствовало накоплению ароматических аминокислот.

Такие незаменимые аминокислоты как триптофан, метионин и лизин находятся в соотношении 1:2:4, что полностью соответствует формуле сбалансированного питания и свидетельствует о том, что белки рулетов обладают наилучшей усвояемостью.

В таблице 2 приведены данные, характеризующие пищевую ценность, а также степень удовлетворения суточной потребности в биологически активных веществах при потреблении 100 г разработанных рулетов.

Таблица 2 - Содержание макро- и микронутриентов в рулетах, в 100 г

\begin{tabular}{|c|c|c|c|c|}
\hline \multirow{2}{*}{$\begin{array}{c}\text { Наименование } \\
\text { показателя }\end{array}$} & \multicolumn{2}{|c|}{ Рулет } & \multirow{3}{*}{$\begin{array}{c}\text { Суточная } \\
\text { потребность } \\
{[6]}\end{array}$} & \multirow{3}{*}{$\begin{array}{c}\text { Степень } \\
\text { удовлетворения } \\
\text { суточной } \\
\text { потребности, \% }\end{array}$} \\
\hline & «Тюменский» & «Застольный» & & \\
\hline \multicolumn{3}{|c|}{ Макромикроэлементы, мг/ 100 г } & & \\
\hline Кальций & 15,6 & 14,8 & 1200 & $1,31-1,25$ \\
\hline Фосфор & 163,0 & 166,0 & 1200 & $13,6-13,8$ \\
\hline Калий & 265,0 & 261,7 & 2500 & $10,5-10,6$ \\
\hline Натрий & 20,3 & 19,5 & 400 & $0,48-0,5$ \\
\hline Магний & 25,3 & 25,0 & 400 & $6,2-6,3$ \\
\hline Железо & 2,67 & 2,63 & 15 & $17,8-17,5$ \\
\hline Марганец & 0,019 & 0,017 & 5 & $0,33-0,37$ \\
\hline Медь & 0,1 & 0,09 & 1 & $9,0-10$ \\
\hline Цинк & 1,9 & 1,86 & 12 & $12,4-12,7$ \\
\hline \multicolumn{3}{|c|}{ Витамины, мг /100 г } & & \\
\hline Е (токоферол) & 0,38 & 0,44 & 15 & $2,5-2,9$ \\
\hline $\mathrm{B}_{1}$ (тиамин) & 0,09 & 0,09 & 15 & 6,0 \\
\hline & 0,12 & 0,13 & 1,8 & $6,7-7,2$ \\
\hline (рибофлавин) & 0,22 & 0,26 & 2 & $11,0-13,0$ \\
\hline $\begin{array}{l}\text { В6 } \\
\text { (пиридоксин) } \\
\text { РP (ниацин) }\end{array}$ & 4,56 & 4,81 & 21 & $0,22-0,23$ \\
\hline
\end{tabular}

Как видно из полученных данных, разработанные образцы рулетов являются хорошим источником калия, магния, фосфора, железа, меди и цинка, а также витаминов группы В и витамина $\mathrm{E}$. 
Нами были проведены также микробиологические исследования, которые показали, что разработанные рулеты копчено-вареные соответствуют нормам, регламентированным СанПиН 2.3.2.560-96.

Таким образом, обоснована возможность использования мяса кроликов при производстве копчено-вареных продуктов, а результаты исследований дают основание считать, что разработанные продукты содержат в своем составе физиологически функциональные ингредиенты незаменимые аминокислоты, витамины, минеральные вещества, что свидетельствует, об их высокой биологической ценности.

\section{Список литературы}

1. Распоряжение правительства РФ № 1873-p от 25 октября 2010г. [Электронный ресурс].

2. Общая технология мяса и мясопродуктов / И.А. Рогов, А.Г. Забашта, Р.М. Ибрагимов, Л.Л. Забашта. - М.: Колос, 2000. - 367 с.

3. Волкова О.В. Разработка и товароведная характеристика продуктов из мяса кролика: дис...на соиск. уч. степ. канд. техн. наук. Кемерово, 2009. - 125 с.

4. Волкова О.В. Морфологический состав качества отрубов тушки кроликов / О.В. Волкова, К.С. Есенбаева // Современные концепции развития науки: сб. стат. Межд.-науч. практ. конф. (28 января 2017 г., г. Екатеринбург). В 3 ч. 3./ -Уфа: МЦИИ ОМЕГА САЙНС, 2017. С. 43-45.

5. ГОСТ 9959-2015 Мясо и мясные продукты. Общие условия проведения органолептической оценки. - М.: Изд-во стандартов, 2016. -19 с.

6. Методические рекомендации 2.3.1.2432-08. Нормы физиологических потребностей в энергии и пищевых веществах для различных групп населения Российской Федерации.

\section{References}

1. Rasporjazhenie pravitel'stva RF № 1873-r ot 25 oktjabrja 2010g. [Jelektronnyj resurs].

2. Obshhaja tehnologija mjasa i mjasoproduktov / I.A. Rogov, A.G. Zabashta, R.M. Ibragimov, L.L. Zabashta. - M.: Kolos, 2000. - 367 s.

3. Volkova O.V. Razrabotka i tovarovednaja harakteristika produktov iz mjasa krolika: dis...na soisk. uch. step. kand. tehn. nauk. Kemerovo, 2009. - 125 s.

4. Volkova O.V. Morfologicheskij sostav kachestva otrubov tushki krolikov / O.V. Volkova, K.S. Esenbaeva // Sovremennye koncepcii razvitija nauki: sb. stat. Mezhd.-nauch. prakt. konf. (28 janvarja 2017 g., g. Ekaterinburg). V 3 ch. 3./ -Ufa: MCII OMEGA SAJNS, 2017. S. 43-45.

5. GOST 9959-2015 Mjaso i mjasnye produkty. Obshhie uslovija provedenija organolepticheskoj ocenki. - M.: Izd-vo standartov, 2016. -19 s.

6. Metodicheskie rekomendacii 2.3.1.2432-08. Normy fiziologicheskih potrebnostej v jenergii i pishhevyh veshhestvah dlja razlichnyh grupp naselenija Rossijskoj Federacii. 